\title{
Engine performance and exhaust emissions of Garcinia gummi-gutta based biodiesel-diesel and ethanol blends
}

\author{
B. S. Ajith ${ }^{1} \cdot$ M. C. Math ${ }^{2} \cdot$ G. C. Manjunath Patel ${ }^{3} \cdot$ Mahesh B. Parappagoudar $^{4}$
}

Received: 26 June 2020 / Accepted: 25 March 2021 / Published online: 7 April 2021

(c) The Author(s) 2021 OPEN

\begin{abstract}
The use of abundantly available Garcinia gummi-gutta seeds grown at forest lands and ethanol a by-product of sugar industries has led to resource conservation and their use as alternate fuel to diesel engines for pollution reduction. Garcinia gummi-gutta (GGG) oil-based methyl esters blended with $20 \%$ ethanol and diesel fuel composed of six fuel samples (D100, B20E20, B30E20, B40E20, B100E20 and B100) are tested at different engine loads $(0 \%, 20 \%, 40 \%, 80 \%$ and $100 \%)$ for their practical usefulness in diesel engine. Six fuel samples are tested for fuel properties. Biodiesel-diesel-ethanol blends showed approximately closer fuel properties to standard diesel fuel. Tests are carried out experimentally to know their performance and emission characteristics of six test samples fuelled in diesel engine varied subjected to different loads. Brake specific fuel consumption for all biodiesel blends is slightly higher for diesel fuel and its proportion decreases with increase in engine load. At full load engine condition, the brake thermal efficiency (BTE) for diesel fuel is $26.25 \%$, and for biodiesel blends vary in the ranges of 22.5 to $25.2 \%$. Compared to diesel fuel there is a reduction in $32.56 \%$ of carbon monoxide (CO) emission and $35.71 \%$ of hydrocarbon (HC) emission for biodiesel fuel (B100E20). For all biodiesel blended fuels tested at all engine loads, the oxides of nitrogen (NOx) emissions are marginally higher than diesel fuel. At full load engine condition, B100E20 (100\% diesel and 20\% ethanol) reduces CO emissions by $6.45 \%$, $\mathrm{HC}$ emissions by $6.64 \%$, and increases BTE by $0.8 \%$, compared to neat biodiesel (B100). GGG based biodiesel blended with ethanol resulted with better fuel properties, performance and emission characteristics to that of diesel fuel. Garcinia gummi-gutta seed yields $45 \%$ of oil with a high conversion ratio to biodiesel of 1:0.96, which help the industry for biodiesel production in large scale at reduced cost.
\end{abstract}

\section{Article Highlights}

- Garcinia gummi-gutta non-food grain low-cost feedstock grown in forest land is used for biodiesel production.

- Fuel properties of biodiesel were found to improve.

- Exhaust emissions were found to be less than diesel. This will lead to minimize pollution.

Keywords GGG Seed $\cdot$ Ethanol $\cdot \mathrm{BSFC} \cdot \mathrm{BTE} \cdot \mathrm{HC} \cdot \mathrm{CO}$ and NOx

G.C. Manjunath Patel, manju09mpm05@gmail.com | 'Department of Mechanical Engineering, Sahyadri College of Engineering and Management, Mangaluru, Visvesvaraya Technological University, Belagavi, India. ${ }^{2}$ Department of Thermal Power Engineering, Visvesvaraya Technological University Post Graduation Studies, Mysuru, Visvesvaraya Technological University, Belagavi,

India. ${ }^{3}$ Department of Mechanical Engineering, PES Institute of Technology and Management, Shivamogga, Visvesvaraya Technological University, Belagavi, India. ${ }^{4}$ Department of Mechanical Engineering, Padre Conceicao College of Engineering, Verna, Goa, India. 


\begin{tabular}{|c|c|}
\hline \multicolumn{2}{|c|}{ Abbreviations } \\
\hline ASTM & American society for testing and materials \\
\hline BSFC & Brake specific fuel consumption \\
\hline bTDC & Before top dead centre \\
\hline BTE & Brake thermal efficiency \\
\hline B100 & 100\% Biodiesel \\
\hline B20E20 & $\begin{array}{l}20 \% \text { Biodiesel }+20 \% \text { ethanol }+60 \% \text { diesel }(\% \\
\text { by volume) }\end{array}$ \\
\hline B30E20 & $\begin{array}{l}30 \% \text { Biodiesel }+20 \% \text { ethanol }+50 \% \text { diesel }(\% \\
\text { by volume) }\end{array}$ \\
\hline B40E20 & $\begin{array}{l}40 \% \text { Biodiesel }+20 \% \text { ethanol }+40 \% \text { diesel }(\% \\
\text { by volume) }\end{array}$ \\
\hline B100E20 & $100 \%$ Biodiesel $+20 \%$ ethanol ( $\%$ by volume) \\
\hline $\mathrm{CO}$ & Carbon monoxide \\
\hline cSt & Centistokes \\
\hline $\mathrm{CO}_{2}$ & Carbon dioxide \\
\hline $\mathrm{CH}_{3} \mathrm{ONa}$ & Sodium methoxide \\
\hline D100 & 100\% Diesel \\
\hline GC-MS & Gas chromatography mass spectrometry \\
\hline GGG & Garcinia gummi-gutta \\
\hline GGGCO & Garcinia gummi-gutta Crude oil \\
\hline $\mathrm{HC}$ & Hydrocarbon \\
\hline PM & Particulate matter \\
\hline NOx & Oxides of nitrogen \\
\hline
\end{tabular}

\section{Introduction}

Today many countries economic growth rely mainly on the energy (crude oil) as exporter. This occurs due to energy considered being the necessary input for industrialization and modernization in improving human welfare, quality of life, economic growth and social development [1]. Stringent government environmental regulations limit to use burning of fossil fuels and their depletion made research attention towards alternate energy sources. Although efforts made towards indigenous production, but still many countries (including India) is dependent heavily on the crude oil import to meet present day energy crisis. In India, demand for diesel may rise from 52.33 million tonnes by 2006 to 104.3 million tonnes by 2020 . Diesel engines are the essential part of industries all around the globe, as they possess excellent characteristics such as high torque, durable and fuel economy under wide range of conditions [2]. Transportation (road and rail), electricity production, civil construction, mining, agriculture and maritime are the major sectors operated with diesel engines [3]. Increased world-wide applications resulted in decreased underground carbon resources, climate change and global warming. Diesel engine emit harmful $\mathrm{CO}, \mathrm{HC}$, and $\mathrm{NO}_{x}$ emissions [4]. High PM causes lung diseases, neurodegenerative disorders, cardiovascular diseases, irregularities in heart beat and heart attacks [5]. CO emissions substitute the oxygen in human blood which creates the malfunction in body's metabolism [6]. $\mathrm{NO}_{\mathrm{x}}$ emission not only affects the lung and respiratory problems but also results in acid rain which finally affects the terrestrial and aquatic life [7]. Including India, many other countries trying for sustainable alternative resources to limit the critically facing energy crisis, environmental pollution and associated health issues.

Sustainable renewable sources (biofuels namely alcohol and biodiesel) paying significant attention in recent times alternate to conventional diesel fuels $[5,8]$. In particular, biodiesel performance in diesel engines are studied by many authors [9-12]. The information corresponding to various feedstocks and techniques employed for oil extraction, necessary for biodiesel production is mentioned in the literature [9]. The performance, combustion and emission characteristics of biodiesel fuels are discussed. Further, their advantages towards practical utility in diesel engines were analysed [10]. Engine performance and emission characteristics of honge and cotton seeds biodiesel were tested at different load conditions with homogeneous charge compression ignition $(\mathrm{HCCl})$ type engine [11]. The performances of compressed natural gas with air and diesel/hone oil with methyl ester were tested on both $\mathrm{HCCl}$ and dual fuel type engines [12]. The results had shown that, biodiesel is promising alternate fuel for diesel engines.

Rapid progress takes place in biodiesel research are due to the following reasons, biodegradable, non-toxic, high flash point, reduced sulfur content and exhaust emissions $\left(\mathrm{HC}, \mathrm{CO}, \mathrm{PM}, \mathrm{NO}_{\mathrm{X}}\right.$ ), approximately similar properties to diesel fuel, and direct fuel injection to the engine with or without modification $[13,14]$. Ministry of Railways of government of India reported that diesel consumption raises to approximately two billion litres/year [15]. Even small reduction of $20-40 \%$ in conventional diesel fuel substitute with alternate fuels, could save around $400-800$ million litres/year. This successfulness can only be accomplished by limiting the practical disadvantages of biodiesel namely, higher values of viscosity, $\mathrm{NO}_{\mathrm{x}}$ emissions, cloud and pour point, low volatility and energy content, high cost, low engine speed and power (i.e. $5 \%$ less power compared to diesel fuel), poor cold flow property [8]. The above literature inferred that the biodiesels are potential substitutes to diesel fuel, provided their disadvantages are limited that enable maximum biodiesel production and usage.

To meet stringent energy demand, strict government regulations on environment pollutions and health hazards with fossil fuels, led many research efforts focussed towards biodiesel production. Alternate fuels are indeed essential to meet the stringent demand due to rise in population, depletion of natural resources and increasing 
pollution level [16]. Biodiesel productions are derived from various feedstock such as animal fats (chicken, beef and duck tallow, fish fat, pork lard), plant oils (cotton seed, rapeseed oil, karanj, mahua, corn, soya bean, palm, peanut, sunflower, coconut, castor, kapok, lupin, beechnut, linseed, olive, maize, grapeseed, and so on) $[17,18]$. To reduce the operational problems in diesel engines, the high viscosity fuel, derived from animal and plant oils must be transesterified to alkyl esters [17]. Biodiesel is effective only when their production cost is less than the petroleumbased diesel fuel for commercialization. Raw material price for some feed stock (plant oils and animal fats) alone constitutes approximately $70-90 \%$ of total biodiesel cost $[19,20]$. Feedstock choice is largely rely on geographical location, available resources, crops, and crude petroleum price. The world second largest population is India, which in turn requires huge agriculture land for growing food grains for their livelihood. Use of agriculture land specifically for growing plants towards biodiesel production is not economically competent compared to petroleumbased diesel fuel. It is to be noted that, feed stock cost of most of animal fats and plant oils are found to be higher than petroleum-based diesel fuel. This is the major drawback and hinders their commercialization. Therefore, significant attention must be paid to explore cost effective novel feedstock for biodiesel production.

GGG tree is a tropical Guttiferae family species native to India [21]. The Garcinia gummi-gutta trees grown in evergreen forests regions of coastal saline belt (states: Karnataka and Kerala) and western Ghats of India. GGG tree yield seeds which are of non-food grain type used for extraction of oils which are essential for biodiesel production. Garcinia gummi-gutta grown in forests (protect fertile agriculture land), and government do not restrict their harvesting of fruits which are necessary for biodiesel production. GGG is a miscellaneous application tree, wherein their fruits, barks, leaves and roots contain distinguished photochemical used for many biological activities and hence high medicinal value. The fruit rind is used for preparing food curries and garnish. The fruits contain high concentration of Vitamin $C$ which cures heart diseases. Resin obtained from the tree, after processing was used for the treatment of tumour, fever, ulcers, and parasites [22]. High concentration of hydroxy citric acids present in fruits are excellent source to use as ani-obesity drug and helps natural weight loss [23]. The old trees provide necessary shade to coffee and other commercial crops, in addition to their use in furniture and construction preparation [24]. The seed cake after oil extraction may help to prepare bio-composites for commercial product applications. Leaves enhance the fertility of soil as they are very good compost. Glycerol a by-product after oil extraction can be used in paints, cosmetics, soap, tooth pastes, textile, leather, hair conditioner, pharmaceutical and food industries $[25,26]$. Therefore, Garcinia gummi-gutta is a novel low-cost feed stock due to their wide applications can be used for biodiesel production in industries at large scale to compensate the energy demand that contribute towards economic growth. GGG based biodiesel blended with diethyl ether additive was employed and their practicality was tested with diesel engine [27]. Diethyl ether production is done using the acid clay catalyst from ethanol. Ethanol boiling point is approximately two times that of diethyl ether and therefore ease of handling, transport and storage [28]. Diethyl ether is highly flammable and harmful to skin and other diseases. Ethanol productions are abundantly available and can be extracted as a byproduct in sugar production industries. Therefore, ethanol is cost competent compared to diethyl ether. Positive impacts of use of bioethanol helps in reduction of noxious emissions [29]. The results obtained were found to be satisfactory and need extensive research to test with other additives for their suitability and commercialization. Significant attention must be paid to use ethanol as additive (alternate to diethyl ether) to biodiesel for better fuel properties, performance and emission characteristics.

Garcinia gummi-gutta seeds are non-food grain type, which are grown at large scales in the forest (do not require fertile land unlike food grain crops, vegetables etc.) regions of Karnataka state. It is to be noted that, ethanol is obtained as a by-product of sugar cane industries and require significant attention towards effective waste management system. Further, GGG fruits, barks, leaves and roots possess high medicinal value, and their by-products after oil extraction may be used in many industries for commercial applications. Ethanol has greater potential to improve the fuel properties of gancinia gummigutta based biodiesel. However, not much of the work is reported in the literature on testing engine performance and exhaust emissions. The present work is focussed mainly on the practicality of Garcinia gummi-gutta based biodiesel with additive ethanol as a fuel for diesel engines require evaluation for commercialization. Thereby, Garcinia gummi-gutta based bio-diesel with different proportion of biodiesel-diesel-ethanol blended fuel is evaluated for fuel properties (viscosity, flash point, fire point, density, gross calorific value), performance (BSFC, BTE) and emission (CO, $\mathrm{HC}$ and $\mathrm{NO}_{x}$ ) characteristics. Therefore, the impact of ethanol on biodiesel (B100) has been tested for fuel properties, performance and emission characteristics with varying loads. Further, the suitability of biodiesel-diesel-ethanol blends is evaluated for fuel properties, performance and emission characteristics, and compared with conventional diesel fuel.

In the present work, engine performance and exhaust emissions of diesel, biodiesel and biodiesel-ethanol 
blends are studied at different engine loads, aiming to replace diesel with garcinia gumm-gutta based biodiesel. In Sect. 2, feedstock materials and their oil extraction, and method of biodiesel blend preparations are discussed. Testing of fuel properties, experiments performed on diesel engines with overall uncertainty analysis are also discussed. In Sect. 3, results of diesel, biodiesel and biodiesel-ethanol blends are presented and discussed. Concluding remarks from the results of experimental studies are discussed in Sect. 4.

\section{Materials and methods}

\subsection{Materials}

GGG is a hardwood tree grow up to $18 \mathrm{~m}$ tall. These trees grow in the dense forest regions of Western Ghats of India (Karnataka, Kerala, Maharashtra and Tamilnadu). Since, Garcinia gummi-gutta tree also grown in homesteads of coastal saline belt. The tree generally yields $30-50 \mathrm{~kg}$ of fruits. The fruits are generally of spherical circular shape with an average dimension of $6 \mathrm{~cm}$ in diameter and $7 \mathrm{~cm}$ of height (refer Fig. 1). One kg of dried fruits can be obtained from 6-10 fruits. Each fruit contains $6-8$ seeds and each seed weighs approximately $1.5-1.7 \mathrm{gm}$. The average size of ovoid shaped seed is $3 \mathrm{~cm} \times 1 \mathrm{~cm}$ and are generally brown
Table 1 The fatty acid composition of Garcinia gummi-gutta seed oil

\begin{tabular}{lr}
\hline Fatty acid, structure & \% wt \\
\hline Linolenic acid, (C18:3) & 0.29 \\
Linoleic acid, (C18:2) & 1.36 \\
Palmitic acid, (C16:0) & 2.52 \\
Stearic acid, (C18:0) & 40.52 \\
Oleic acid, (C18:1) & 54.93 \\
\hline
\end{tabular}

in colour (refer Fig. 1). The seeds yielded at an average of $45 \%$ oil and its conversion to production of biodiesel in the ratio of 1:0.96. GGG seeds essential for production of biodiesel was collected from Balehonnur, Karnataka. GGG seed oil is tested to know the free fatty acid composition using gas chromatograph (refer Table 1).

\subsection{Method of extraction of Garcinia gummi-gutta seed oil}

Indian industries and academic institution installed mechanical expeller units for the method of oil extraction. Mechanical expeller consisting of constantly rotating screw placed inside the cylindrical barrel. The seeds are pressed between the barrel and screw during rotation and in turn push the crushed seed in the direction parallel to its axis. Gradual increase in pressure tends to crush the seed which finally releases the oil and crushed seed cake
Fig. 1 Garcinia-gummigutta tree, fruit and seed

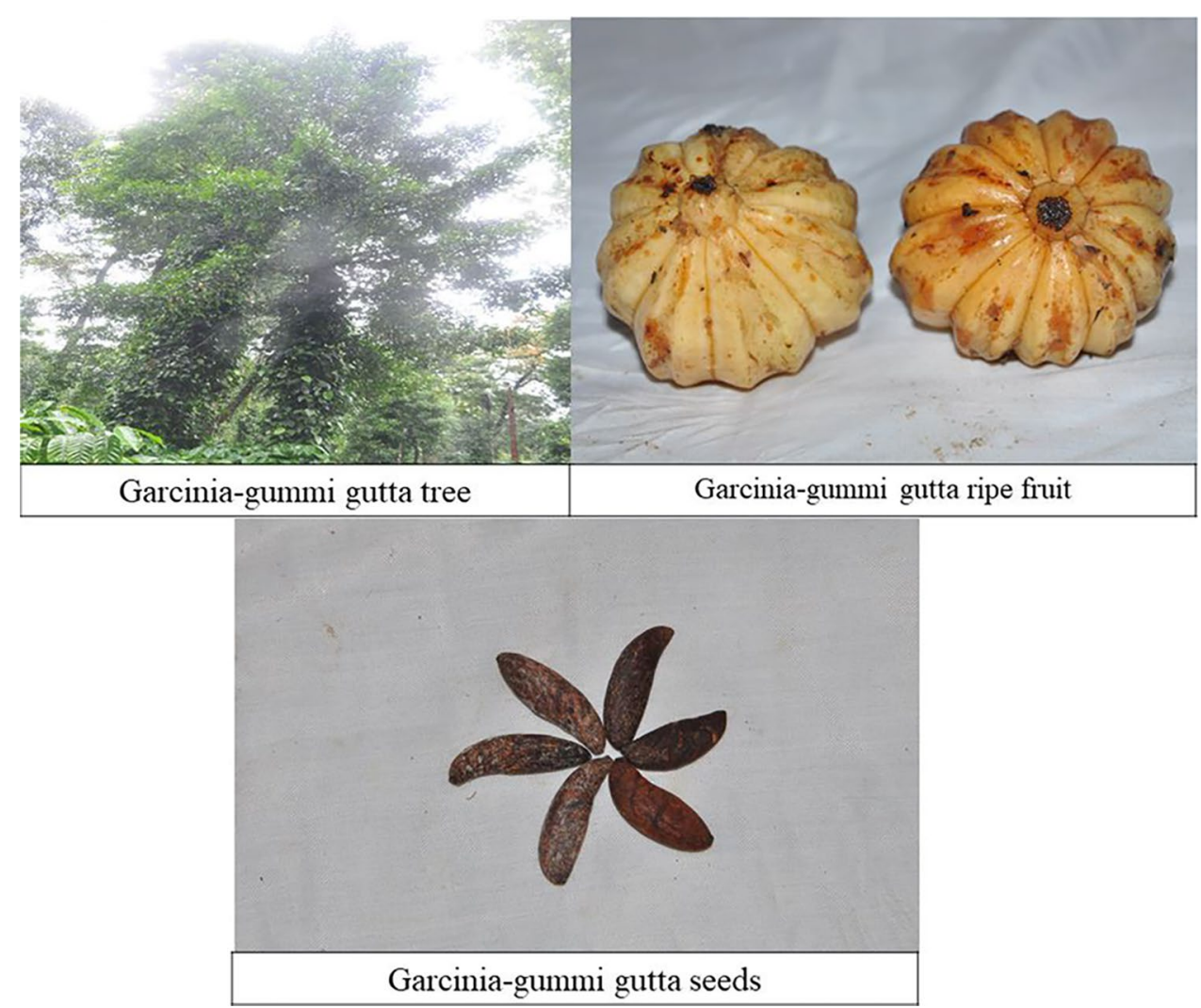


are collected at different slots provided on the periphery of the barrel. The collected oil was filtered for removal of unwanted particles (present if any) to obtain pure GGG seed oil.

Biodiesel synthesis is conducted by using transesterification process. The process is synthesised using one litre three neck bottomed flask with a magnetic stirrer, reflux condenser and hot plate. The steps followed in transesterification process is explained below,

1. As received Garcinia gummi-gutta pure oil is heated initially to a temperature of $80^{\circ} \mathrm{C}$ for about $15-20 \mathrm{~min}$ to remove water (present if any).

2. The metered quantity of oil taken in a flask is continuously stirred on a hot plate at temperature $55^{\circ} \mathrm{C}$. This process is carried out to melt the solid particles present if any.

3. Continuous stirring of the mixture (oil and $50 \%$ sodium methoxide $\mathrm{CH}_{3} \mathrm{ONa}$ solution) is carried out for 5-10 min.

4. The remaining $50 \%$ of $\mathrm{CH}_{3} \mathrm{ONa}$ solution is added and continue the stirring process for about 15-20 min.

5. After heating the mixture to $60^{\circ} \mathrm{C}$ at different reaction time, the process of stirring and heating the solution is stopped. Then the solution is allowed to cool at room temperature for about $8 \mathrm{~h}$.

6. Two phase solution is obtained upon cooling, consisting of methyl ester on the upper phase and glycerine in the bottom phase.

7. Methyl ester is obtained after separating layers by sedimentation process. Traces of catalyst (if any) present in biodiesel was removed by centrifugation.

Table 2 Optimal biodiesel yield from transesterification process

\begin{tabular}{lcl}
\hline Transesterification parameters & Optimal value & Biodiesel yield \\
\hline Sodium hydroxide, (\%w/v of oil) & 0.83 & $96.2 \%$ \\
Reaction time, $\min$ & 60.0 & \\
Reaction temperature, ${ }^{\circ} \mathrm{C}$ & 60.0 & \\
Methanol, (\% v/v of oil) & 40.0 & \\
\hline
\end{tabular}

8. Pure Garcinia gummi-gutta oil was extracted by removing methanol after undergoing distillation process. The yield of methyl ester was estimated by using Eq. (1).

$$
\text { Yield of Methyl Ester }=\frac{W t \text {. of methyl ester produced }}{W t \text {. of oil taken for reaction }} \times 100
$$

The different sets of methanol, sodium hydroxide and reaction time are varied experimentally to optimize for maximum biodiesel yield. The values correspond to optimized transesterification variables resulted with the maximum yield of $96.2 \%$ (refer Table 2).

\subsection{Biodiesel blend preparation}

The fuel properties, performance and exhaust emissions of diesel engine fuelled with four types of biodiesel fuel are investigated. The effect of three component ratios (ethanol-biodiesel-diesel) of biodiesel fuel, biodiesel variations are focussed significantly in the prepared blends. Ethanol in biodiesel blended fuel could reduce the dry soot emission in particulate matter, and gasses emissions (HC, CO and NOx) are added advantages [30]. As per India's National Policy on Biofuels, low percentage of biodiesel blends are studied. Moreover, higher biodiesel blends are also studied to provide complete insight on the mixing of three component ratios and their fuel properties, performance and emission characteristics of biodiesel. The blends are prepared at different proportion of ethanol, diesel and biodiesel with stirring placed on a magnetic stirring plate. Six test samples such as, B20E20 (20\% of biodiesel, $20 \%$ ethanol and $60 \%$ diesel) B30E20 (30\% biodiesel, $20 \%$ ethanol and 50\% diesel), B40E20 (40\% biodiesel, $20 \%$ ethanol and 40\% diesel), B100E20 (100\% biodiesel, $20 \%$ ethanol), B100 (100\% biodiesel) and D100 (100\% diesel) are used for the present research work.

\subsection{Testing of fuel properties}

Table 3 presents the fuel properties of GGGCO, biodiesel-diesel-ethanol blends, diesel and biodiesel. Increased proportion of biodiesel tends to increases the viscosity and density of fuel samples. Garcinia gummi-gutta
Table 3 Fuel properties of biodiesel-diesel-ethanol blends

\begin{tabular}{lllllllll}
\hline Property & GGGCO & Diesel & Ethanol & B20E20 & B30E20 & B40E20 & B100E20 & B100 \\
\hline Viscosity at $40{ }^{\circ} \mathrm{C}(\mathrm{cSt})$ & 46 & 4.1 & 1.1 & 4.23 & 4.32 & 4.56 & 4.71 & 5.43 \\
Density at $15^{\circ} \mathrm{C}\left(\mathrm{kg} / \mathrm{m}^{3}\right)$ & 850 & 800 & 821 & 804 & 808 & 812 & 816 & 820 \\
Flash point, ${ }^{\circ} \mathrm{C}$ & 220 & 54 & 13 & 77.2 & 91.3 & 98.7 & 155 & 185 \\
Fire point, ${ }^{\circ} \mathrm{C}$ & 230 & 59 & - & 89.3 & 104.1 & 114.5 & 161 & 192 \\
Higher calorific value, $\mathrm{MJ} / \mathrm{kg}$ & 38.2 & 44.8 & 27 & 43.7 & 42.4 & 41.3 & 40.8 & 40.1 \\
Cetane index & - & 50 & 8 & 39 & 41 & 47 & 52 & 54 \\
\hline
\end{tabular}


biodiesel (B100) resulted with highest density and viscosity, and lowest obtained with the diesel fuel. Note that, biodiesel possess $2.5 \%$ higher density and $17.81 \%$ higher viscosity than the diesel fuel. Furthermore, Garcinia gummi-gutta crude oil (GGGCO) possess very high viscosity, density and low calorific value (say, correct is $17.27 \%$ ) compared to diesel. The complex chemical structure and large molecular weight are the result of higher properties (density and viscosity) of biodiesel (refer Tables 1 and 3). Table 3 showed that GGG based biodiesel resulted with higher flash and fire point than diesel fuel. High flash and fire point of biodiesel could favour in terms of ease of handling, storage, and transportation. Table 3 clearly states the GGGCO subjected to transesterification process reduces the viscosity, density and improve the calorific value. Sodium hydroxide catalyst tends to improve the chemical reaction time that takes place between the triglycerides and alcohol reduces viscosity of crude oil. Higher calorific or heating value was observed for diesel than biodiesel and its various blends.

Gas chromatography tests are performed to know the percent composition of saturated and unsaturated fatty acid extracted from GGGCO. The saturated fatty acid composition constitutes $43.04 \%$, whereas the rest $56.58 \%$ of unsaturated acid. The presence of saturated fatty acid increases the cetane number and stability. Higher cetane number is desirable that ensure complete combustion and reduce emissions [31]. Ethanol mixes completely with diesel fuel at higher temperature (i.e., above room temperature), whereas at low temperatures solubility of ethanol is low. In the present work, small proportion of ethyl acetate is added to improve the miscibility of ethanol-biodiesel blends. However, ethanol as additive to biodiesel reduces the viscosity and noise. Moreover, it improves ignition and combustion process in diesel engines. Ethanol concentration of $20 \%$ will enhance the oxygen fraction (i.e. $16 \%$ excess air than diesel), which will eliminate soot emission and reduce particulate matter [32].

\subsection{Experimental procedure and engine specification}

Fuels are tested at an engine speed maintained with fixed value of $1500 \mathrm{rpm}$. Figure 2 show the representation of engine setup, and its detailed technical description is presented in Table 4. Experimentally the engine load is varied between the ranges from $0-100 \%$, with the 5 incremental steps of $20 \%$ (i.e. $0 \%, 20 \%, 40 \%, 60 \%, 80 \%$ and $100 \%$ ). In each incremental load of $20 \%$ the biodiesel blended fuels are examined for emission and performance characteristics. Note that the biodiesel blends resulted with the

Table 4 Engine specifications

\begin{tabular}{ll}
\hline Make & Kirloskar (India) \\
\hline Engine model & TV1 \\
Type & $\begin{array}{c}\text { Four stroke, direct injection, } \\
\text { variable compression } \\
\text { ratio }\end{array}$ \\
Number of cylinders & One \\
Bore $\times$ stroke $(\mathrm{mm})$ & $87.5 \times 110$ \\
Rated output $(\mathrm{kw})$ & 5.2 \\
Compression ratio & $17.5: 1$ \\
Rated speed (rpm) & 1500 \\
Cooling mode & Water-cooled \\
Aspiration type & Naturally aspirated engine \\
Injection pressure & 22 MPa \\
Injection timing & $28^{\circ}$ bTDC \\
Dynamo meter & Eddy current dynamometer \\
\hline
\end{tabular}

Fig. 2 Schematic representation of test engine

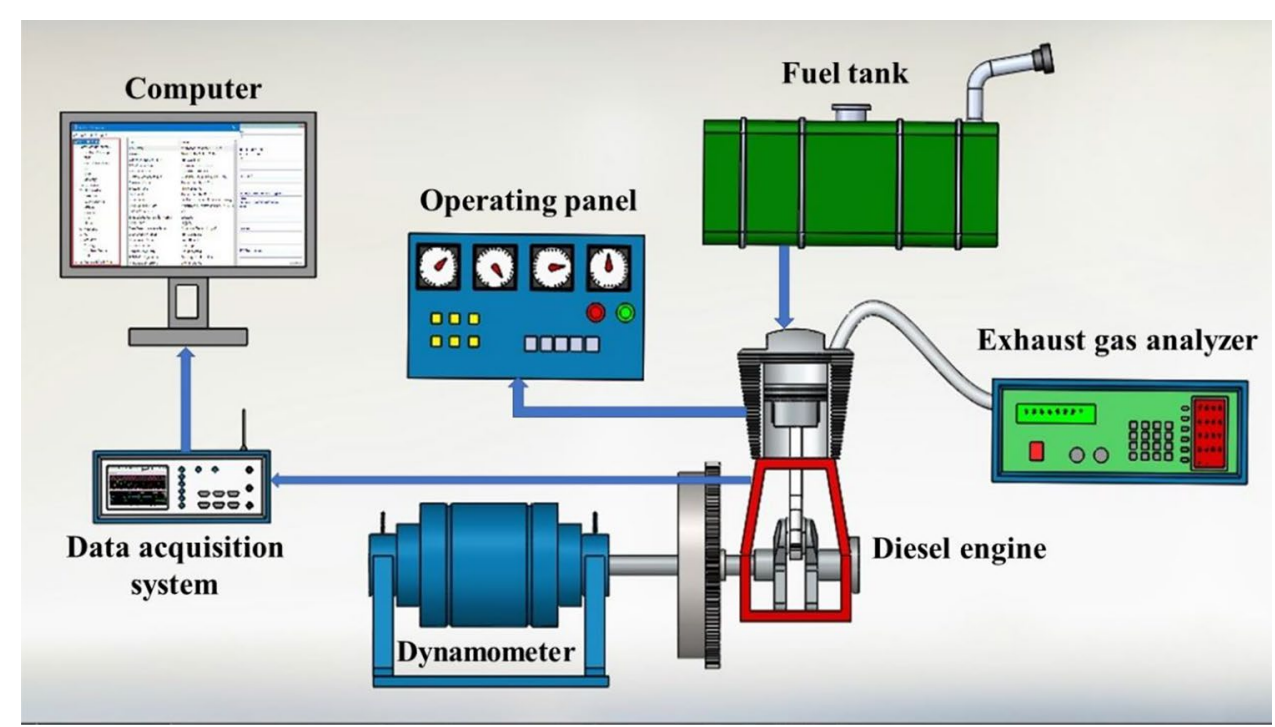


comparable values with diesel fuel. Prior to experimentation, engine was monitored as per catalogue values so as to ensure stable operating conditions and perform accurate analysis. Initially engine starts with diesel fuel, which further allowed to warm up by continuously running the engine (say $30 \mathrm{~min}$ ) till it ensures steady state condition (i.e. oil and water temperatures results in approximately constant value). At all engine loads, the emission and performance characteristics of diesel fuel was tested.

Later, diesel fuel was replaced with biodiesel blends. For every change in fuel, the engine is allowed to continuously run with biodiesel blend (testing fuel) for about $10 \mathrm{~min}$ till the residual (previously tested) fuel ensured completely drained from the fuel line, prior to data acquisition (i.e. performance and emission measurements). The exhaust measurement system is designed to comply with BAR-97,

\subsection{Error analysis}

Error or uncertainty analysis are of industrial relevance to know the insight of percent error and accuracy in experiments. The error occurs from experimental results are probably due to instrument precision level, environment and experiment conditions, observation, calibration and reading. Each experiment is repeated thrice to know the uncertainty associated with different variables of measurement. Table 5 present the test results of relative uncertainty of measuring instruments. The engine performance and exhaust emissions vary for each experiment within the ranges shown in Table 5. The overall uncertainty error for the present work from experimental test results is found to be within the range of $\pm 2.92 \%$. Equation (2) is used in computing overall uncertainty.

$$
\begin{aligned}
\text { Overall uncertainity } & =\sqrt{(\text { Load })^{2}+(\text { Fuel flow rate })^{2}+(B S F C)^{2}+(B T E)^{2}+(\mathrm{CO})^{2}+(\mathrm{HC})^{2}+\left(\mathrm{NO}_{X}\right)^{2}} \\
\text { Overall uncertainity } & =\sqrt{(0.64)^{2}+(0.41)^{2}+(0.74)^{2}+(0.84)^{2}+(1.2)^{2}+(1.65)^{2}+(1.60)^{2}} \\
& = \pm 2.92
\end{aligned}
$$

OIML class 0 and ISO3930 International standards. The technical specification of gas analyser used during measurements are given in the "Appendix A". The similar procedure is repeated for other biodiesel blends.

Table 5 Test result summary of uncertainty and experimental accuracy

\begin{tabular}{lll}
\hline Parameters & Accuracy & Uncertainty (\%) \\
\hline Load & $\pm 0.1 \mathrm{~kg}$ & \pm 0.64 \\
BSFC & $\pm 0.05 \mathrm{~g} / \mathrm{kWh}$ & \pm 0.74 \\
HC & $\pm 1 \mathrm{ppm}$ & \pm 1.40 \\
Fuel flow rate & $\pm 0.03 \mathrm{l} / \mathrm{h}$ & \pm 0.41 \\
CO & $\pm 0.01 \mathrm{vol} \%$ & \pm 1.20 \\
BTE & \pm 0.6 & \pm 0.84 \\
NOx & $\pm 1 \mathrm{ppm}$ & \pm 1.45 \\
\hline
\end{tabular}

\section{Results and discussion}

The results of performance (BSFC, BTE) and emission characteristics (CO, HC, NOx) with the engine load for diesel (D100), biodiesel (B100) and biodiesel-ethanol-diesel blends (B20E20, B30E20, B40E20, B100E20, and B100) are discussed below.

\subsection{Brake specific fuel consumption}

The fuel properties (density, viscosity, calorific value) are being the primary factors influence the BSFC of diesel engines. Figure 3a show the BSFC variations of tested fuel samples (D100, B20E20, B30E20, B40E20, B100E20 and $B 100)$ with the engine load. Figure $3 a$ showed that all the biodiesel blends resulted with higher BSFC, compared to diesel fuel. Higher BSFCs for all tested fuels are
Fig. 3 Performance variations at different conditions of fuels versus engine load): a BSFC, and $\mathbf{b}$ BTE
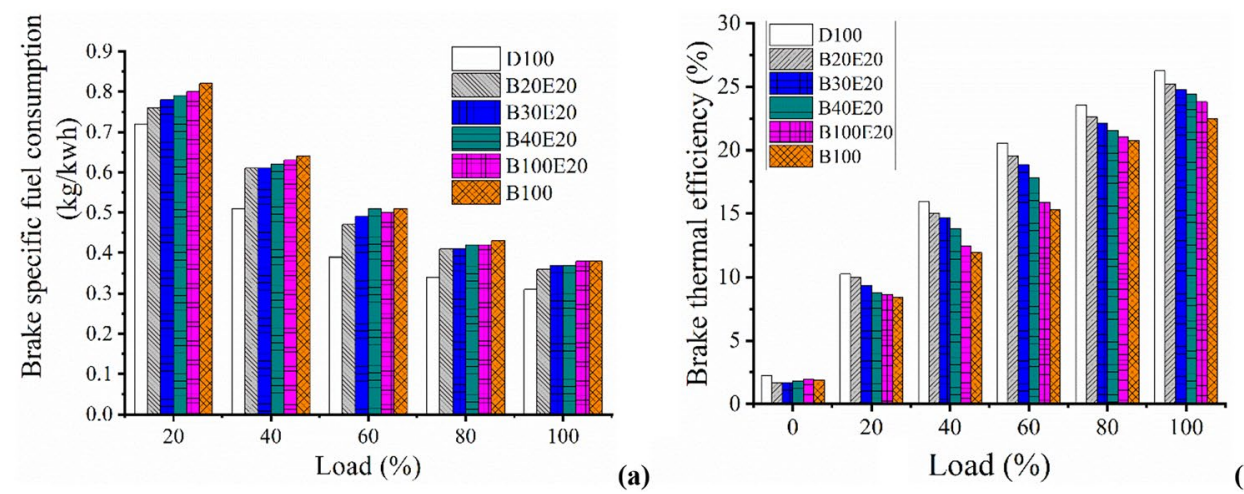

(b) 
observed under no-load conditions compared to full load condition. Increased ratio of fuel atomization being the probable reason. At $1500 \mathrm{rpm}$ under full load condition the BSFC of D100 and B100 fuels were 0.31 and $0.38 \mathrm{~kg} / \mathrm{kWh}$, respectively. This clearly signify that increased percent of biodiesel require extra fuel to generate the same engine power output. The BSFC of B20E20, B30E20, B40E20, $\mathrm{B} 100 \mathrm{E} 20$ and $\mathrm{B} 100$ was $16.1 \%, 19.4 \%, 19.4 \%, 22.6 \%$ and $22.6 \%$, higher than diesel. BSFC rate rely mainly on lower heating value, ethanol possesses lower heating value (energy contained in the fuel) than that of diesel fuel. Note that, BSFC rate decreases with proportion of ethanol contained in the fuel blends. At full load, impact of ethanol does not alter the brake specific fuel consumption of biodiesel (refer Fig. 3a). Maximum of $25 \%$ BSFC was observed for the palm-oil based biodiesel [33]. The BSFCs of tested fuels are in line with the results obtained for palm oil-based biodiesel. The fuel characteristics (higher density and viscosity, lower calorific and heating value), during combustion advanced fuel injection time could results in higher BSFC in biodiesel blends [34, 35]. The said reasons are in line with the tested fuel properties shown in Table 3.

\subsection{Brake thermal efficiency}

BTE of engine fuelled with D100, B20E20, B30E20, B40E20, $B 100 E 20$ and $B 100$ fuels tested at different engine load conditions, are shown in Fig. 3b. At all engine loading conditions, the BTE of biodiesel blends are found marginally lower than diesel fuel (refer Fig. 3b). At 1500 rpm under full-load operating condition (100\%), BTE was $26.25 \%$ for diesel, 25.2\% for B20E20, 24.8\% for B30E20, 24.4\% for B40E20, 23.8\% for B100E20 and 22.5\% for B100 fuel. Lower BTE resulted with biodiesel blends are due to the poor volatility and combustion characteristics (incomplete combustion as a result of lack of air content), low calorific, higher density and viscosity value compared to diesel [4, 36]. Higher biodiesel viscosity limits in adequate breaking of biodiesel during the injection process, which affects the BTE [37]. At full engine loading condition, the brake thermal efficiency of B100E20 increases by $0.8 \%$ compared to B100. Higher volatility of ethanol improves mixing velocity of air/fuel mixture that ensures rapid combustion, which in turn enhance the brake thermal efficiency.

\subsection{Carbon monoxide emission}

Figure 4a show the $\mathrm{CO}$ emission variations with engine loads tested against the all fuels. Increase in biodiesel in the blended fuel resulted in decreased values of $\mathrm{CO}$ emissions at all engine loads. At full load conditions, $C O$ emissions of B20E20, B30E20, B40E20, B100E20 and B100 are $11.63 \%, 13.95 \%, 20.93 \%, 32.56 \%$ and $27.91 \%$ lower than diesel fuel. This is because of the presence of higher oxygen content in the biodiesel could proportionately improve the combustion phenomenon at faster rate. Note that, the oxygen content proportionately increases with increased percent of biodiesel in the prepared blends. The presence of ethanol in biodiesel tested at full load engine conditions, B100E20 decreases the $\mathrm{CO}$ emissions by $6.45 \%$ compared to B100. Higher heat of vaporization of neat biodiesel (B100) than ethanol (B100E20) emits higher amount of $\mathrm{CO}$. The inherent oxygen present in biodiesel makes easier to burn the fuel efficiently at high temperature in the cylinder (i.e. better combustion) and hence results in low emission. The results are in line with the other literature $[36,37]$.

\subsection{Hydrocarbon emission}

Figure $4 \mathrm{~b}$ show the $\mathrm{HC}$ emission variation with engine load tested for the all fuels. $\mathrm{HC}$ emission increases with the increased proportion in engine load (refer Fig. 4b). Low HC emission at engine part load (no load) might be of higher fuel mixture with low oxygen proportion resulting from the engine operation. At full engine loading conditions, HC emissions of B20E20, B30E20, B40E20, B100E20 and B100 fuels are $7.14 \%, 14.28 \%, 21.43 \%, 35.71 \%$ and $28.57 \%$ lower than the diesel fuel. At all loads, the biodiesel blends resulted in low HC emission compared diesel fuel. This is
Fig. 4 Emission variations at different conditions of fuels versus engine load: a $\mathrm{CO}, \mathbf{b} \mathrm{HC}$, and c NOx
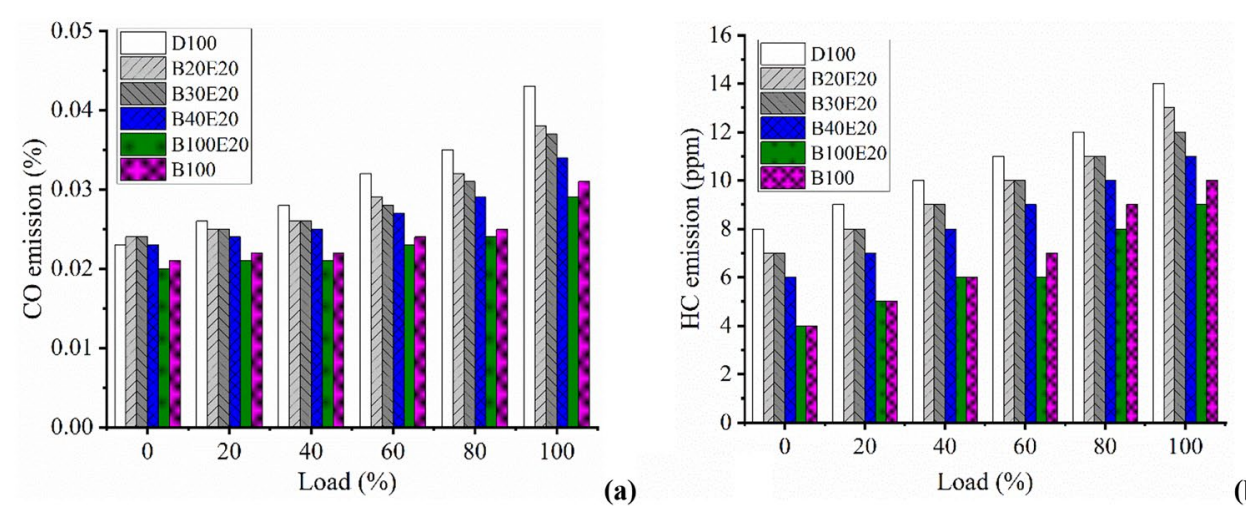
because of biodiesel possess favourable fuel characteristics such as higher cetane number, oxygen content and increased gas temperature (reduce the condensation of rich hydrocarbons in the fuel) compared to diesel fuel [36, 37]. High cetane number causes reduction in combustion delay which decreases the $\mathrm{HC}$ emissions in biodiesel [31]. At full load engine condition, the $\mathrm{HC}$ emissions of B100E20 decrease by $6.64 \%$ compared to B100. Ethanol additive to biodiesel improves oxygen content and fuel characteristics (i.e. reduces viscosity and density) leads to enhanced spray improved spray and atomization characteristics. This results in lower $\mathrm{HC}$ emissions.

\subsection{Nitrogen oxide emission}

NOx formation in the engines is primarily dependent on adiabatic flame temperature in turn cylinder temperature [38]. NOx emission variation with different fuels tested at different loading conditions are presented in Fig. 4c. At fixed no-load and full load engine condition the lower and higher emission values are equal to 25 and $90 \mathrm{ppm}$ for diesel fuel, 28 and 95 ppm for B20E20, 32 and 99 ppm for B30E20, 34 and 102 ppm for B40E20, 38 and 112 ppm for B100E20 and 40 and 116 ppm for B100, respectively. The NOx emission of B100E20 decrease by $3.45 \%$ at full load engine conditions compared to B100. Reduced NOx emissions are due to the cooling effect of ethanol, low calorific value and higher latent heat of vaporisation could lower the combustion temperature. NOx emission tends to increase with engine load (varied from $0-100 \%$ ) for all fuels. When the engine operates at higher load there will be large amount of fuel burnt that offer better combustion characteristics led to high engine cylinder temperature resulted in high NOx emissions. Biodiesel blends showed high NOx emission values than diesel fuel at all engine load conditions. Higher cylinder temperature and oxygen content are probable reasons for the biodiesel to result in increased emission values of NOx. These results are in line with the literature [36-39].

\section{Conclusions}

Garcinia gummi-gutta based biodiesel blended fuels tested under different loads to know their impact on performance and emission characteristics are discussed below,

1. The density, viscosity, flash and fire points of biodiesel blended fuels (B20E20, B30E20, B40E20, B100E20 and $B 100)$ are slightly higher than diesel fuel. High flash and fire point of biodiesel is best suited to store, handle and ease of transportation. Biodiesel blends resulted with low calorific value than diesel fuel.
2. All Biodiesel blends resulted with higher BSFC and lower BTE than the diesel fuel. High viscosity and density, change in combustion and ignition timing, low calorific value, poor volatility and combustion characteristics are the probable reasons for the said results.

3. At all engine loading conditions, biodiesel blends resulted with lower emissions $(\mathrm{CO}$ and $\mathrm{HC}$ ) than diesel fuel. CO emissions of B20E20, B30E20, B40E20, $\mathrm{B} 100 \mathrm{E} 20$ and $\mathrm{B} 100$ are $11.63 \%, 13.95 \%, 20.93 \%$, $32.56 \%$ and $27.91 \%$ lower than diesel fuel. At full load engine condition, the $\mathrm{HC}$ emissions of B20E20, B30E20, B40E20, B100E20 and B100 fuels are $7.14 \%, 14.28 \%$, $21.43 \%, 35.71 \%$ and $28.57 \%$ lower than the diesel fuel. The said results are explained with increased gas temperature and oxygen content that facilitates complete fuel combustion with biodiesel blends compared to diesel (D100).

4. Ethanol addition to neat biodiesel (i.e. B100E20) reduces $\mathrm{CO}$ emissions by $6.45 \%, \mathrm{HC}$ emissions by $6.64 \%$, and increases BTE by $0.8 \%$, compared to neat biodiesel (B100).

5. Increased percent of biodiesel fuel in the prepared blends increases the NOx emissions. Higher oxygen content and cylinder temperature (i.e. combustion) being the major reason for higher NOx emission for biodiesel than the diesel fuel.

6. High flash and fire points, reduced emissions (CO and $\mathrm{HC}$ ) and acceptable calorific value, density, viscosity, and NOx emissions of biodiesel-ethanol-diesel blends led to be the potential substitute to diesel fuel.

7. The novel Garcinia gummi-gutta seeds contain $45 \%$ of oil with higher conversion ratio to biodiesel of 1:0.96 for production. From literatures it was confirmed that the GGG is a miscellaneous stray hardwood tree grown in forests, wherein its leaves, fruits, roots, bark and tree possess both medical and commercial values. Therefore, effective waste management of garcinia-gummi gutta seeds and ethanol a by-product of sugar industries could be useful for biodiesel production in industry at large scale with low cost for meeting the stringent energy demand.

8. The present research work can be extended in many directions such as, application of nano-catalyst in biodiesel production, preparation of biodiesel-ethanol-diethyl ether blends to explore the advantages of these blends on engine performance and exhaust emissions.

Acknowledgements The authors acknowledge VTU, Belagavi, Competitive Research Fund (Reference: VTU/TEQIP 3/2019/321) under TEQIP Program for their financial support.

Declarations 
Conflict of interest Authors declare that there is no potential conflict of interest in publishing this article.

Open Access This article is licensed under a Creative Commons Attribution 4.0 International License, which permits use, sharing, adaptation, distribution and reproduction in any medium or format, as long as you give appropriate credit to the original author(s) and the source, provide a link to the Creative Commons licence, and indicate if changes were made. The images or other third party material in this article are included in the article's Creative Commons licence, unless indicated otherwise in a credit line to the material. If material is not included in the article's Creative Commons licence and your intended use is not permitted by statutory regulation or exceeds the permitted use, you will need to obtain permission directly from the copyright holder. To view a copy of this licence, visit http://creativecommons. org/licenses/by/4.0/.

\section{Appendix A: Technical specifications of gas analyzer}

\begin{tabular}{|c|c|c|c|c|}
\hline $\begin{array}{l}\text { Measure- } \\
\text { ment } \\
\text { parameter }\end{array}$ & $\begin{array}{l}\text { Principle of meas- } \\
\text { urement }\end{array}$ & Range & $\begin{array}{l}\text { Resolu- } \\
\text { tion }\end{array}$ & $\begin{array}{l}\text { Accu- } \\
\text { racy }\end{array}$ \\
\hline $\mathrm{CO}$ & NDIR & $0-15 \%$ & $0.001 \%$ & $\pm 3 \%$ \\
\hline $\mathrm{HC}$ & NDIR & $0-20,000$ ppm & $1 \mathrm{ppm}$ & $\pm 5 \%$ \\
\hline $\mathrm{NO}_{\mathrm{x}}$ & Electrochemical & $0-5000$ ppm & $1 \mathrm{ppm}$ & $\pm 3 \%$ \\
\hline \multirow[t]{2}{*}{ RPM } & Battery/magnetic & 400-9990 & 10 & $\pm 2 \%$ \\
\hline & Piezo & $400-6000$ & 1 & $\pm 2 \%$ \\
\hline OT & RTD & $0-150{ }^{\circ} \mathrm{C}$ & $1^{\circ} \mathrm{C}$ & $\pm 3 \%$ \\
\hline $\begin{array}{l}\text { Operating } \\
\text { tempera- } \\
\text { ture }\end{array}$ & $0-50^{\circ} \mathrm{C}$ & & & \\
\hline $\begin{array}{l}\text { Measuring } \\
\text { gas intake }\end{array}$ & $1 \mathrm{ltr} / \mathrm{min}$ & & & \\
\hline $\begin{array}{l}\text { Response } \\
\text { time }\end{array}$ & \multicolumn{4}{|c|}{$5 \mathrm{~s}$ (for sampling probe length of $3 \mathrm{~m}$ ) } \\
\hline $\begin{array}{l}\text { Warm-up } \\
\text { time } \\
\left(\geq 25^{\circ} \mathrm{C}\right)\end{array}$ & \multicolumn{4}{|l|}{$2 \min$} \\
\hline $\begin{array}{l}\text { Zero/gas } \\
\text { span cali- } \\
\text { bration }\end{array}$ & \multicolumn{4}{|l|}{ Automatic/manual } \\
\hline $\begin{array}{l}\text { Span cali- } \\
\text { bration }\end{array}$ & \multicolumn{4}{|l|}{ Digital } \\
\hline Leak test & \multicolumn{4}{|l|}{ Electronic } \\
\hline $\begin{array}{l}\text { Opacity } \\
\text { (HU) }\end{array}$ & Light absorption & $0-99.99 \%$ & $0.01 \%$ & - \\
\hline Opacity (K) & Light absorption & $0-9.99 \%$ & $0.001 / \mathrm{m}$ & - \\
\hline \multirow[t]{2}{*}{ RPM } & Piezo based & $0-6000$ & 1 & - \\
\hline & $\begin{array}{l}\text { Battery based/ } \\
\text { acoustic (mag- } \\
\text { netic) }\end{array}$ & $0-6000$ & 10 & - \\
\hline OT & RTD & $0-150^{\circ} \mathrm{C}$ & $1^{\circ} \mathrm{C}$ & - \\
\hline Linearity & $\pm 0.1 / \mathrm{m}$ & & & \\
\hline $\begin{array}{l}\text { Repeatabil- } \\
\text { ity }\end{array}$ & $\pm 0.1 / \mathrm{m}$ & & & \\
\hline
\end{tabular}

\begin{tabular}{|c|c|c|c|}
\hline $\begin{array}{l}\text { Measure- } \\
\text { ment } \\
\text { parameter }\end{array}$ & $\begin{array}{l}\text { Principle of meas- Range } \\
\text { urement }\end{array}$ & $\begin{array}{l}\text { Resolu- } \\
\text { tion }\end{array}$ & $\begin{array}{l}\text { Accu- } \\
\text { racy }\end{array}$ \\
\hline $\begin{array}{l}\text { Zero and } \\
\text { span drift }\end{array}$ & \multicolumn{3}{|l|}{ $\pm 0.1 / \mathrm{m}$} \\
\hline Response & \multicolumn{3}{|l|}{ Physical: ${ }^{<} 0.4 \mathrm{~s}$} \\
\hline time & \multicolumn{3}{|l|}{ Electrical: ${ }^{<} 1 \mathrm{~m} \mathrm{sec}$} \\
\hline $\begin{array}{l}\text { Smoke } \\
\text { column }\end{array}$ & \multicolumn{3}{|c|}{$215 \mathrm{~mm}$ long (430 mm folded length) } \\
\hline $\begin{array}{l}\text { Warm-up } \\
\text { time }\end{array}$ & \multicolumn{3}{|l|}{$<5 \min$} \\
\hline $\begin{array}{l}\text { Wireless } \\
\text { opera- } \\
\text { tions }\end{array}$ & \multicolumn{3}{|l|}{ Bluetooth } \\
\hline $\begin{array}{l}\text { Input Power } \\
\text { Supply }\end{array}$ & \multicolumn{3}{|l|}{ 11-13 VDC/230VAC $\pm 20 \%$} \\
\hline $\begin{array}{l}\text { Power } \\
\text { consump- } \\
\text { tion }\end{array}$ & \multicolumn{3}{|l|}{$75 \mathrm{~W}$} \\
\hline Dimension & \multicolumn{3}{|l|}{$475 \times 170 \times 275 \mathrm{~mm}$} \\
\hline Weight & \multicolumn{3}{|l|}{$8 \mathrm{~kg}$} \\
\hline
\end{tabular}

\section{References}

1. Sahoo PK, Das LM, Babu MKG, Arora P, Singh VP, Kumar NR, Varyani TS (2009) Comparative evaluation of performance and emission characteristics of jatropha, karanja and polanga based biodiesel as fuel in a tractor engine. Fuel 88(9):1698-1707

2. Özener O, Yüksek L, Ergenç AT, Özkan M (2014) Effects of soybean biodiesel on a DI diesel engine performance, emission and combustion characteristics. Fuel 115:875-883

3. Morón-Villarreyes JA, Soldi C, de Amorim AM, Pizzolatti MG, de Mendonça Jr AP, D'Oca MG (2007) Diesel/biodiesel proportion for by-compression ignition engines. Fuel 86(12-13):1977-1982

4. Rosha P, Dhir A, Mohapatra SK (2018) Influence of gaseous fuel induction on the various engine characteristics of a dual fuel compression ignition engine: a review. Renew Sust Energ Rev 82:3333-3349

5. Agarwal AK (2007) Biofuels (alcohols and biodiesel) applications as fuels for internal combustion engines. Prog Energy Combust Sci 33(3):233-271

6. Aydın H, İlkılıç C (2017) Air pollution, pollutant emissions and harmfull effects. J Eng Technol 1(1):8-15

7. Li L, Wang J, Wang Z, Xiao J (2015) Combustion and emission characteristics of diesel engine fueled with diesel/biodiesel/ pentanol fuel blends. Fuel 156:211-218

8. Demirbas A (2007) Progress and recent trends in biofuels. Prog Energy Combust Sci 33(1):1-18

9. Mahmudul HM, Hagos FY, Mamat R, Adam AA, Ishak WFW, Alenezi $R$ (2017) Production, characterization and performance of biodiesel as an alternative fuel in diesel engines-a review. Renew Sust Energ Rev 72:497-509

10. Tamilselvan P, Nallusamy N, Rajkumar S (2017) A comprehensive review on performance, combustion and emission characteristics of biodiesel fuelled diesel engines. Renew Sust Energ Rev 79:1134-1159

11. Khandal SV, Banapurmath NR, Gaitonde VN (2019) Performance studies on homogeneous charge compression ignition 
$(\mathrm{HCCl})$ engine powered with alternative fuels. Renew Energy 132:683-693

12. Hiremath SS, Khandal SV, Banapurmath NR, Math VB, Gaitonde VN (2017) Comparative analysis of performance of dual fuel (DF) and homogeneous charge compression ignition $(\mathrm{HCCl})$ engines fuelled with honne oil methyl ester (HOME) and compressed natural gas (CNG). Fuel 196:134-143

13. Nabi MN, Akhter MS, Shahadat MMZ (2006) Improvement of engine emissions with conventional diesel fuel and diesel-biodiesel blends. Bioresour Technol 97(3):372-378

14. Singh P, Tiwari SK, Singh R, Kumar N (2017) Modification in combustion chamber geometry of $\mathrm{Cl}$ engines for suitability of biodiesel: a review. Renew Sust Energ Rev 79:1016-1033

15. Nalgundwar A, Paul B, Sharma SK (2016) Comparison of performance and emissions characteristics of $\mathrm{DICl}$ engine fueled with dual biodiesel blends of palm and jatropha. Fuel 173:172-179

16. Nanthagopal K, Ashok B, Saravanan B, Pathy MR, Sahil G, Ramesh A, Nabi MN, Rasul MG (2019) Study on decanol and Calophyllum Inophyllum biodiesel as ternary blends in $\mathrm{Cl}$ engine. Fuel 239:862-873

17. Knothe G, Krahl J, Van Gerpen J (2015) The biodiesel handbook. Elsevier, Amsterdam

18. Banković-Ilić IB, Stojković IJ, Stamenković OS, Veljkovic VB, Hung YT (2014) Waste animal fats as feedstocks for biodiesel production. Renew Sust Energ Rev 32:238-254

19. Balat $M$ (2011) Potential alternatives to edible oils for biodiesel production-A review of current work. Energy Convers Manag 52(2):1479-1492

20. Leung DY, Wu X, Leung MKH (2010) A review on biodiesel production using catalyzed transesterification. Appl Energy 87(4):1083-1095

21. Murthy HN, Joseph KS, Payamalle S, Betageri S, Gudodagi R, Mesta S, Kodli S (2017) Garcinia gummi-gutta (L.) Robs.: a promising feedstock for biodiesel production. Int J Green Energy 14(14):1178-1181

22. Jena BS, Jayaprakasha GK, Singh RP, Sakariah KK (2002) Chemistry and biochemistry of (-)-hydroxycitric acid from Garcinia. J Agr Food Chem 50(1):10-22

23. Duke JA (2002) Handbook of medicinal herbs. CRC Press, Boca Raton

24. Orwa C, Mutua A, Kindt R, Jamnadass R, Anthony S (2009) Garcinia gummi-gutta (L.) N. Robson (Clusiaceae) In: Agroforestree Database: a tree reference and selection guide version 4.0. World Agroforestry Centre, Kenya

25. Wendisch VF, Lindner SN, Meiswinkel TM (2011) Use of glycerol in biotechnological applications. In: Biodiesel-quality, emissions and by-products. Intech Open

26. Tan HW, Aziz AA, Aroua MK (2013) Glycerol production and its applications as a raw material: a review. Renew Sust Energ Rev 27:118-127
27. Ajith BS, Math MC, Manjunath Patel GC (2020) Evaluation of performance and emission characteristics of diesel engine fuelled with garcinia gummi gutta biodiesel and diethyl ether blends. Eur J Sustain Dev Res 4(4):0134. https://doi.org/10.29333/ejosdr/ 8353

28. Bailey B, Eberhardt J, Goguen S, Erwin J (1997) Diethyl ether (DEE) as a renewable diesel fuel. SAE Trans 1997:1578-1584

29. Goldemberg J, Coelho ST, Guardabassi P (2008) The sustainability of ethanol production from sugarcane. Energy Policy 36(6):2086-2097

30. Chen H, Shi-Jin S, Jian-Xin W (2007) Study on combustion characteristics and PM emission of diesel engines using ester-ethanol-diesel blended fuels. Proc Combust Inst 31(2):2981-2989

31. Monyem A, Van Gerpen JH, Canakci M (2001) The effect of timing and oxidation on emissions from biodiesel-fueled engines. Trans ASAE 44(1):35

32. De Caro PS, Mouloungui Z, Vaitilingom G, Berge JC (2001) Interest of combining an additive with diesel-ethanol blends for use in diesel engines. Fuel 80(4):565-574

33. Ndayishimiye P, Tazerout M (2011) Use of palm oil-based biofuel in the internal combustion engines: performance and emissions characteristics. Energy 36(3):1790-1796

34. Nabi MN, Rahman MM, Akhter MS (2009) Biodiesel from cotton seed oil and its effect on engine performance and exhaust emissions. Appl Therm Eng 29(11-12):2265-2270

35. Lin YC, Hsu KH, Chen CB (2011) Experimental investigation of the performance and emissions of a heavy-duty diesel engine fueled with waste cooking oil biodiesel/ultra-low sulfur diesel blends. Energy 36(1):241-248

36. Abed KA, El Morsi AK, Sayed MM, El Shaib AA, Gad MS (2018) Effect of waste cooking-oil biodiesel on performance and exhaust emissions of a diesel engine. Egypt J Pet 27(4):985-989

37. Buyukkaya E (2010) Effects of biodiesel on a DI diesel engine performance, emission and combustion characteristics. Fuel 89(10):3099-3105

38. Anand K, Sharma RP, Mehta PS (2011) Experimental investigations on combustion, performance and emissions characteristics of neat karanji biodiesel and its methanol blend in a diesel engine. Biomass Bioenerg 35(1):533-541

39. Sakthivel G, Nagarajan G, llangkumaran M, Gaikwad AB (2014) Comparative analysis of performance, emission and combustion parameters of diesel engine fuelled with ethyl ester of fish oil and its diesel blends. Fuel 132:116-124

Publisher's Note Springer Nature remains neutral with regard to jurisdictional claims in published maps and institutional affiliations. 